\title{
PENGARUH CURRENT RATIO, RETURN ON ASSET, DAN DEBT TO EQUITY RATIO TERHADAP HARGA SAHAM PERUSAHAAN MAKANAN DAN MINUMAN DI BURSA EFEK INDONESIA PERIODE 2015-2017
}

\author{
Anna \\ annanana292@gmail.com \\ Universitas Ahmad Dahlan \\ Salamatun Asakdiyah \\ salamatun_2009@yahoo.com \\ Universitas Ahmad Dahlan
}

\begin{abstract}
ABSTRAK
The research was conducted to test the current, ratio return on assets, and debt to equity ratio on the price of food and beverage company shares in the indonesia stock exchange. 2015-2017 periodThis peneltian mengetaui (1) is there to influence current ratio, stock prices (2) is there the return on assets against, stock prices (3) is there the influence of debt to equity ratio of, stock prices (4) does influence together current, ratio return on assets, and debt to equity ratio on the price of food and minumana shares in companies listed on the indonesia stock exchange. 2015-2017 period. The population in this study is a food and beverage company listed on the IDX. The sample selection uses a purposive sampling method. The total sample of 11 food and beverage companies is listed on the IDX in the period 2015-2017. Data analysis using classical assumption test and panel data model regression analysis. Based on the results of the study show that (1) Current Ratio partially has a positive and not significant effect on stock prices, (2) Return on Asset partially has a positive and significant effect on stock prices, (3) Debt to Equity Ratio partially has a negative effect and not significant to stock prices, (4) Current Ratio, Return on Assets, and Debt to Equity Ratio simultaneously have a positive and significant effect on stock prices, this is evidenced by the $\mathrm{R} 2$ value of 0.322021 and F significance value of 4.591398 .
\end{abstract}

Keywords: Current Ratio, Return On Asset, Debt To Equity Ratio, and Stock Price

\footnotetext{
PENDAHULUAN

Setiap orang dihadapkan pada berbagai pilihan dalam penentuan penggunaan dana atau sumber daya yang dimiliki baik untuk konsumsi saat ini maupun saat mendatang. Investasi dapat berkaitan dengan penanaman sejumlah dana pada asset real seperti: tanah, emas, rumah dan asset real lainnya atau pada asset finansial seperti; deposito, saham, obligasi, dan surat berharga lainnya.

Industri makanan dan minuman masih menjadi sektor andalan penopang
}

pertumbuhan manufaktur di Indonesia. Industri pengolahan merupakan sektor tertinggi yang memberi kontribusi dalam sektor ekonomi. Sebagian besar di antaranya merupakan industri pengolahan nonmigas. Dari industri tersebut, makanan dan minuman memiliki porsi kontribusi terbesar yakni 6,33 persen terhadap PDB nasional semester I 2018. Selebihnya berasal dari industri kimia sebesar 2,9 persen, barang logam, komputer, dan mesin sebesar 2,08 persen, alat angkutan sebesar 1,76 persen, serta tekstil dan pakaian jadi sebesar 1,13 persen. Subsektor makanan dan minuman juga 
mengalami pertumbuhan tertinggi dibandingkan industri manufaktur lainnya. Pentingnya sektor strategis ini terlihat dari peningkatan realisasi investasi. Dari lima investasi sektor industri, paling besar dari makanan dan minuman sebesar Rp 29,14 triliun. Sementara industri kimia memiliki nilai investasi $\mathrm{Rp}$ 28,97 triliun, barang logam, komputer, barang elektronik, dan mesin sebesar $\mathrm{Rp} 18,89$ triliun, alat

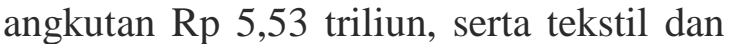
pakaian jadi sebesar Rp 4,65 triliun. Selama 2014-2018, pemerintah telah mengembangkan 13 kawasan industri baru di pulau Jawa dan luar Jawa. Pengembangan juga dilakukan dengan menambah 22 sentra industri kecil dan menengah di 22 kota/kabupaten di luar pulau Jawa (Kompas.com).

Perusahaan makanan dan minuman merupakan salah satu kategori sektor industri di Bursa Efek Indonesia (BEI) yang mempunyai peluang untuk tumbuh dan berkembang. Industri makanan dan minuman diprediksi akan membaik kondisinya. Hal ini terlihat semakin menjamurnya industri makanan dan minuman di negara ini khususnya semenjak memasuki krisis berkepanjangan. Kondisi ini membuat persaingan semakin ketat sehingga para manajer perusahaan berlomba-lomba mencari investor untuk menginvestasikan dananya diperusahaan makan dan minuman tersebut.

Barang konsumsi menjadi industri yang penting bagi perkembangan perekonomian bangsa. Hal ini tidak terlepas dari perusahaan-perusahaan yang bergerak dalam industri barang konsumsi di Indonesia. Tidak bisa dipungkiri bahwasannya dalam proses produksi barang konsumsi dibutuhkan banyak sumber daya termasuk di dalamnya sumber daya manusia. Industri barang konsumsi mempunyai peranan dalam menyerap tenaga kerja dan meningkatkan pendapatan pada suatu negara.

Kepercayaan para investor dan calon investor sangat bermanfaat bagi perusahaan, karena tinggi rendahnya kepercayaan pada perusahaan tentu akan mempengaruhi harga saham perusahaan. Harga saham merupakan salah satu indikator suatu perusahaan. Dimana jika harga saham suatu perusahaan terus mengalami kenaikan maka suatu perusahaan dapat dikatakan berhasil mengelola kinerja keuangan usahanya. Perusahaan yang berhasil mengelola usaha tentu akan meningkatkan kepercayaan para investor untuk berinvestasi.

Investor menginvestasikan dananya ke dalam pasar modal dengan mengharapkan adanya capital gain atau adanya deviden. Kegiatan berinvestansi memerlukan suatu informasi yang lengkap tentang kondisi dan kinerja perusahaan yang akan ditanamkan modalnya tersebut guna meminimalisir kerugian atas resikoresiko yang kemungkinan muncul dalam kegiatan investasinya.

Dalam dunia usaha, Perusahaan yang Go Public juga menerapkan berbagai macam metode agar perusahaan dapat maju dan bersaing. Perusahaan yang sudah Go Public yang terdaftar diberbagai pasar modal dan pasar saham, seperti perusahaan yang tedaftar di Bursa Efek Indonesia (BEI), termasuk perusahaan dibidang makanan dan minuman. Investor asing maupun swasta akan mengamati dan megukur sejauh mana kinerja keuangan perusahaan dalam meningkatkan dan mendapatkan keuntungan sebelum menanamkan dananya kepada perusahaan yang diliriknya.

Investor sangat mempertimbangakan dalam memutuskan investasinya salah satu yang menjadi perhatian investor dalam memutuskan investasinya dapat diketahui dari harga saham perusahaan yang akan dilakukan investansi, dikarenakan harga saham merupakan cerminan dari kondisi perusahaan secara umum. Faktor lain yang turut mempengaruhi harga saham adalah faktor makro ekonomi suatu negara seperti pertumbuhan ekonomi, inflasi, faktor keamanan. 
Tinggi rendahnya minat seorang investor dalam melakukan investasi saham dipengaruhi oleh kualitas nilai saham di pasar modal. Penilaian investasi saham dapat dilakukan dengan berbagai cara seperti dengan menggunakan analisis teknikal maupun analisis fundamental. Menurut Abdul Halim (2003:17-25), terdapat berbagai model analisis terhadap harga saham yaitu analisis fundamental dan analisis teknikal. Analisis fundamental menyatakan bahwa saham memiliki nilai intrinsik tertentu (nilai yang seharusnya). Analisis fundamental membandingkan nilai intrinsik suatu saham dengan harga pasarnya guna menentukan apakah harga pasar saham mencerminkan nilai intrinsiknya atau belum.

Perusahaan mempunyai berbagai macam usaha dalam menarik jumlah investor dan meningkatkan harga sahamnya, salah satunya yaitu dengan mengevalusi faktor-faktor yang sangat berpengaruh terhadap peningkatan harga saham suatu perusahaan. Beberapa faktor yang menyebabkan harga saham diantaranya current ratio, return on asset, dan debt to equity ratio.

Tujuan penelitian dalam konteks penelitian ini untuk mengetahui pertumbuhan current ratio berpengaruh terhadap harga saham pada perusahaan makanan dan minuman yang terdaftar di Bursa Efek Indonesia, serta untuk mengetahui return on asset berpengaruh terhadap harga saham pada perusahaan makanan dan minuman yang terdaftar di Bursa Efek Indonesia. Untuk mengetahui debt to equity ratio berpengaruh terhadap harga saham pada perusahaan makanan dan minuman yang terdaftar di Bursa Efek Indonesia serta untuk mengetahui current ratio, return on asset, dan debt to equity ratio berpengaruh terhadap harga saham pada perusahaan makanan dan minuman yang terdaftar di Bursa Efek Indonesia.

\section{REVIEW LITERATUR DAN HIPOTESIS}

\section{Pasar Modal}

Pasar modal adalah pertemuan antara pihak yang memiliki kelebihan dana dengan pihak yang membutuhkan dana dengan cara memperjualbelikan sekuritas. Dengan demikian, pasar modal juga diartikan sebagai pasar untuk memperjual belikan sekuritas yang umumnya memiliki umur lebih dari satu tahun, seperti saham dan obligasi (Tandelilin, 2001:13).

Menurut Kasmir (2012:182) pengertian pasar modal secara umum merupakan suatu tempat bertemunya para penjual dan pembeli untuk melakukan transaksi dalam rangka memperoleh modal. Penjual dalam pasar modal merupakan perusahaan yang membutuhkan modal (emiten), sehingga mereka berusaha untuk menjual efek-efek di pasar modal. Sedangkan pembeli (investor), adalah pihak yang ingin membeli modal di perusahaan yang menurut mereka menguntungkan.

\section{Saham}

Saham (stock) dapat didefinisikan sebagai tanda penyertaan atau kepemilikan seseorang atau badan dalam suatu perusahaan atau perseorangan terbatas. Saham berwujud selembar kertas yang menerangkan bahwa pemilik kertas tersebut adalah pemilik perusahaan yang menerbitkan surat berharga tersebut. Porsi kepemilikan ditentukan oleh seberapa besar penyertaan yang ditanamkan. Saham merupakan surat bukti bahwa kepemilikan atas aset-aset perusahaan yang menerbitkan saham. Dengan demikian, maka investor akan mempunyai hak terhadap pendapatan dan kekayaan perusahaan, setelah dikurangi dengan pembayaran semua kewajiban perusahaan (Tandelilin, 2001).

\section{Harga Saham}

Harga saham merupakan nilai sekarang dari arus kas yang akan diterima oleh pemilik saham dikemudian hari. Menurut Anoraga (2001:100) harga saham 
adalah uang yang dikeluarkan untuk memperoleh bukti penyertaan atau kepemilikan suatu perusahaan. Harga saham juga diartikan sebagai harga yang dibentuk dari interaksi para penjual dan pembeli saham yang dilator belakangi oleh harapan terhadap profit perusahaan, untuk itu investor memerlukan informasi yang berkaitan dengan pembentukan saham tersebut dalam mengambil keputusan menjual atau membeli saham.

\section{Analisis Rasio Keuangan}

Analisis keuangan merupakan teknik analisis dalam bidang manajemen keuangan yang dimanfaatkan sebagai alat ukur kondisi keuangan suatu perusahaan dalam periode tertentu, ataupun hasil-hasil usaha dari suatu perusahaan pada satu periode tertentu dengan jalan membandingkan dua buah variable yang diambil dari laporan keuangan perusahaan, baik daftar neraca maupun laba rugi (Irawati, 2005:22).

\section{Current Ratio}

Current ratio merupakan perbandingan aktiva lancar dan kewajiban lancar dan merupakan ukuran yang paling umum digunakan untuk mengetahui kemampuan suatu perusahaan memenuhi kewajiban suatu perusahaan memenuhi kewajiban jangka pendeknya. Current ratio menunjukkan sejauh mana aktiva lancar perusahaan dapat menutupi kewajiban lancar semakin tinggi kemampuan perusahaan menuntupi kewajiban jangka pendeknya semakin baik perusahaan menjamin hutang-hutangnya.

Current ratio yang rendah biasanya dianggap menunjukkan terjadinya masalah dalam likuiditas atau kemampuan yang rendah dalam pembayaran kewajiban jangka pendeknya, sebaliknya current ratio yang selalu tinggi juga kurang baik, karena menunjukkan banyaknya dan menganggur atau tidak dikelola dengan baik yang paada akhirnya dapat mengurangi kemampuan perusahaan (Sawir:2009).

\section{Return On Asset (ROA)}

Return On Asset (ROA) rasio ini mengambarkan perputaran aktiva diukur dari volume penjualan. Semakin besar rasio ini semakin baik. Hal ini berarti bahwa aktiva dapat lebih cepat berputar dan meraih laba (Harahap, 2015:305). Return On Asset (ROA) mengukur kemampuan perusahaan dalam memanfaatkan aktivanya untuk memperoleh laba. Rasio ini mengukur tingkat pengembalian investasi yang telah dilakukan oleh perusahaan dengan menggunakan seluruh dana (aktiva) yang dimilikinya. Rasio ini dapat dibandingkan dengan tingkat bunga yang berlaku.

$$
\text { Return On Asset (ROA) }
$$

menunjukkan kemampuan perusahaan dengan menggunakan seluruh aktiva yang dimiliki untuk menghasilkan laba setelah pajak. Rasio ini penting bagi pihak manajemen untuk mengevalusi efektivitas dan efesiensi manajemen perusahaan dalam mengelola seluruh aktiva perusahaan. Semakin besar ROA, berarti semakin efesien penggunaan aktiva perusahaan atau dengan kata dengan jumlah aktiva yang sama bisa dihasilkan laba yang lebih besar, dan sebaliknya.

\section{Debt To Equity Ratio (DER)}

Uang merupakan komponen penting perusahaan khususnya sebagai salah satu sarana pendanan. Sering terjadi penurunan kinerja perusahan sehingga kesulitan dalam memenuhi kewajiban tersebut. Darmadji dan Fakruddin (2011: 158) Debt to Equity Ratio (DER) merupakan rasio yang mengukur sejauh mana besarnya uang dapat ditutupi oleh modal sendiri. Sedangkan menurut Sudana (2009:23) Debt to Equity Ratio (DER) ini merupakan proporsi dana yang bersumber dari utang untuk membiayai aktiva perusahaan. Semakin besar rasio ini menunjukkan porsi penggunaan utang dalam membiayai investasi pada aktiva semakin besar, yang berarti pula risiko 
keuangan perusahaan meningkat dan sebaliknya.

\section{Hipotesis}

H1: Pengaruh Current Ratio (CR) terhadap harga saham.

H2 : Pengaruh Return On Asset (ROA) terhadap harga saham.

H3 : Pengaruh Debt to Equity Ratio (DER) terhadap harga saham.

\section{METODE PENELITIAN}

\section{Populasi dan Sampel}

Populasi merupakan keseluruhan karakteristik atau unit hasil pengukuran yang menjadi objek penelitian atau populasi merupakan objek dan subjek yang berada pada suatu wilayah dan memenuhi syarat-syarat tertentu berkaitan dengan masalah penelitian (Suwarno, 2010). Populasi dalam penelitian ini adalah perusahaan Makanan dan Minuman yang terdaftar di Bursa Efek Indonesia periode 2015-2017 yang berjumlah 15 perusahaan.

Sampel adalah bagian dari populasi yang mempunyai ciri-ciri atau keadaan tertentu yang akan diteliti. Karena tidak semua data dan informasi akan diproses dan tidak semua oranag atau benda kan ditekiti melainkan cukup dengan menggunakan sampel yang mewakili (Suwarno, 2010). Sampel yang digunakan dalam penelitian ini adalah perusahaan yang termasuk dalam kelompok industri makanan dan minuman yang terdaftar di Bursa Efek Indonesia periode 2015-2017.

\section{Jenis Sumber Data}

Menurut jenis dan sumbernya, data yang digunakan dalam penelitian ini adalah data sekunder, yaitu data yang diambil secara tidak langsung dari sumbernya. Data sekunder biasanya diambil melalui dokumen-dokumen (laporan, karya tullis oralng lain, majalah, dan koran). Dalam penelitan ini menggunakan data berupa laporan keuangan perusahaan-perusahaan makanan dan minuman yang terdaftar di Bursa Efek Indonesia yang diterbitkan pada periode 2015-2017. Data sekunder ini diperoleh dari industri makanan dan minuman yang listing di BEI melalui situs Bursa Efek Indonesia (www.idx.co.id).

\section{Teknik Pengumpulan Data}

Teknik pengumpulan data dalam penelitian ini adalah metode dokumentasi. Dokumentasi merupakan catatan peristiwa yang sudah berlalu, yang dapat berbentuk tulisan, gambar, atau karya-karya monumental dari seseorang (Sugiyono, 2016:326). Dokumentasi dari penelitian ini adalah data-data laporan keuangan perusahaan makanan dan minuman yang terdaftar di Bursa Efek Indonesia periode 2015-2017 yang dipublikasikan melalui situs Bursa Efek Indonesia (www.idx.co.id).

\section{Definisi Operasional}

\section{Varibel Dependen (Y)}

Variable dependen (variable terikat) sering digunakan sebagai variable output, kreteria, konsekuen. Merupakan variable yang dipengaruhi atau terjadi akibat, karena adanya varibel bebas (Sugiyono, 2016:64). Dalam penelitian ini yang menjadi varibel dependen adalah harga saham. Harga saham adalah nilai dari suatu saham yang diperjual belikan di Bursa Efek Indonesia yang diukur dengan nilai mata uang, harga saham tersebut ditentukan antara kekuatan demand dan supply.

\section{Variabel Independen (X)}

Variable independent (variable bebas sering disebut variable stimulus, predictor, antecedent. Merupakan variable yang mempengaruhi atau yang menjadi sebab perubahannya atau timbulnya varibel dependen (terikat) (Sugiyono, 2016:64). Variable independent yang digunakan dalam penelitian ini terdiri dari tiga variable diantaranya, yaitu:

a. Current Ratio $\left(X_{1}\right)$ 
Menurut Home (2005:206) rasio lancar adalah untuk menghitung kemampuan perusahaan dalam membayar kewajiban jangka pendek dengan aktiva lancar yang tersedia. Current ratio menunjukkan kemampuan perusahaan untuk melunasi kewajiban jangka pendeknya dari aktiva lancarnya. Rasio ini dihitung dengan membagi aktiva lancar dengan kewajiban jangka pendeknya. Likuiditas jangka pendek ini penting karena bisa mengakibatkan perusahaan bangkrut. Dalam melihat rasio lancar, analisi juga harus diperhatikan kondisi dan lingkungan perusahaan seperti rencana manajem, sektor indusri dan kondisi ekonomi makro secara umum (Darsono dan Ashari, 2005:53). Berikut ini formula untuk menghitung Current ratio $(C R)$ :

$$
\text { Rasio Lancar }=\frac{\text { Aktiva Lancar }}{\text { Utang Lancar }} \times 100 \%
$$

\section{b. Return on Asset $\left(X_{2}\right)$}

Return on Asset (ROA) merupakan bagian dari rasio profitabilitas dalam menganalisis laporan keuangan atas laporan kinerja keuangan perusahaan. Menurut Hanafi (2005:83) Return on Asset adalah rasio yang mengunkur kemampuan perusahaan menghasilkan laba dengan biaya-biaya untuk mendanai asset tersebut, ROA menunujukkan keefesienan perusahaan dalam mengelolah seluruh aktivinya untuk memperoleh pendapatan. Berikut ini formula untuk menghitung Return on Asset (ROA):

$$
R O A=\frac{\text { Laba Sebelum Pajak }}{\text { Aktiva }} \times 100 \%
$$

\section{c. $\quad$ Debt to Equty Ratio $\left(X_{3}\right)$} Menurut Darsono (2005:54), Debt to Equity Ratio adalah rasio yang menunjukkan presentase penyediaan dana oleh pemegang saham terhadap pemberi pinjaman. Semakin tinggi rasio, semakin rendah pendanaan perusahaan yang disediakan oleh pemegang saham. Dari prespektif kemampuan membayar kewajiban jangka Panjang, semakin rendah rasio akan semakin baik kemampuan perusahaan dalam membayar kewajiban jangka panjangnya. Berikut ini formula untuk menghitung Debt to Equity Ratio (DER):

$$
D E R=\frac{\text { Total Utang }(\text { Debt })}{\text { Ekuitas }(\text { Equity) }}
$$

\section{Uji Instrumen \\ Statistik Deskriptif}

Statistik deskirptif adalah statistika yang digunakan untuk menganalisis data dengan cara mendeskripsikan data yang telah terkumpul tanpa bermaksud untuk membuat kesimpualan yang berlaku umum. Statistika deskriptif meliputi penyediaan data dalam bentuk tabel-tabel mengenai perhitungan mean, standar deviasi, nialia minimum dan maksimum.

Adapun persamaan regresi adalah sebagai berikut :

$Y_{i t}=\alpha+\beta 1 X 11_{i t}+\beta 2 X 2_{i t}+\beta 3 X 3_{i t}+e_{i t}$

$\begin{array}{ll}\text { Keterangan: } & \\ \mathrm{Y} & : \text { Log Harga Saham } \\ \alpha & : \text { Konstanta } \\ \beta 1-\beta 3 & : \text { Koefisian Regresi } \\ \mathrm{X} 1 & : \text { Current Ratio } \\ (\mathrm{CR}) & \\ \mathrm{X} 2 & : \text { Return On Asset } \\ (\mathrm{ROA}) & \\ \mathrm{X} 3 & : \text { Debt To Equity } \\ \text { Ratio (DER) } & \end{array}$

\section{a. Uji Normalitas}

Uji normalitas bertujuan untuk membuktikan bahwa data yang dipergunakan berdistribusi normal. Model regresi yang baik adalah distribusi data normal atau mendekati normal (Thoifah, 2015). Uji normalitas menggunakan uji Jarque-Bera dengan menggunakan bantuan progam statistik. Dasar pengambilan keputusan jika probibalitas lebih besar atau sama dengan nilai alpha yang ditentukan, yaitu 5\%, maka data dikatakan 
berdistribusi normal, dan sebaliknya jika probibalitas kurang 5\% maka data berdistribusi tidak normal.

\section{b. Uji Autokorelasi}

Menurut Ghazali (2013:110) pengujian asumsi klasik dalam model regresi linier adalah uji autokorelasi bertujuan untuk menguji apakah dalam suatu model regresi linier ada korelasi antara kesalahan penganggu pada periode t-1 (sebelumnya). Jika terjadi korelasi maka terdapat problem autokorelasi.

Uji autokorelasi dapat dilihat dari Durbin Waton. Apabila nilai DurbinWaston berada pada daerah dU sampai 4-dU kita dapta menyimpulkan bahwa model regresi tidak mengandung autokorelasi. Denga ketentuan sebagai berikkut:
a. $4-\mathrm{dl}<\mathrm{DW}<4$ mempunyai autokorelasi
b. 4-dU $<$ DW $<4-$ dl tidak ada kesimpulan
c. $\mathrm{dU}<\mathrm{DW}<4-\mathrm{dU}$ tidak ada autokorelasi
d. $\quad$ dL $<$ DW $<$ dU tidak ada kesimpulan
e. $0<\mathrm{DW}<\mathrm{dL}$ mempunyai autokorelasi positif

Uji B-G sering juga disebut sebagai uji LM (Lagrange Multiplier). Uji ini dapat menutupi kelemahan pada uji D-W ketika memberikan hasil "tidak ada kesimpulan" . Pengambilan keputusan dapat dilakukan sebagai berikut

Prob. Chi Square > 0,05 tidak ada autokorelasi

Prob. Chi Square $<0,05$ terjadi autokorelasi

\section{c. Uji Heteroskedastisitas}

Pengujian asumsi klasik yang keempat adalah uji heteroskedastisitas (heteriosccdasticity). Pengujian ini bertujuan untuk mengetahui ada tidaknya heteroskedastisitas, dalam hal ini akan dilakukan dengan menggunakan uji statistic, yaitu uji white, Uji ini menggunakan residual kuadrat variabel dependen dan independennya terdiri atas variabel independen yang sudah ada, ditambah dengan kuadrat variabel independen, ditambah dengan perkalian dua variabel independen. Pengambila keputusan dengan menggunakan program Eviews adalah sebagai berikut Prob. chi square (p-value) $>0,05$ tidak terjadi heteroskedastisitas

Prob. chi square (p- value) $<0,05$ terjadi heteroskedastisitas.

\section{d. Uji Multikolinearitas}

Uji Multikolinearitas merupakan salah satu masalah dalam analisis regresi dengan OLS, yang berarti terdapat korelasi atau hubungan yang sangat tinggi diantara variabel variabel independen.

\section{Teknik Analisis Data}

Teknik analisis data yang digunakan dalam penelitian adalah analisis regresi data panel. Model analisis regresi data panel digunakan untuk mengolah data gabungan yang terdiri dari data silang (cross section) dan data runtut waktu (time series).

\section{Uji Chow}

Uji chow ini untuk menentukan apakah menggunakan metode common effect atau metode fixed effect, dengan pertimbangan:

Jika Prob. Chi square $<0,05$, maka fixed effect

Jika Prob. Chi Square > 0,05, maka common effect

Bila hasil menunjukkan common effect, maka penentuan model berhenti sampai disini. Akan tetapi, jika hasil menunjukkan model fixed effect, maka harus dilanjut dengan metode random effect dengan uji Hausman.

\section{Uji Hausman}

Uji Hausman digunakan apabila dalam Uji Chow menghasilkan metode random effect, sehingga harus diuji lagi untuk mengetahui hasilnya apakah metode 
fixed effect atau random effect. Pertimbangan uji Hausman adalah sebagai berikut :

Jika Prob. Cross section random $<0,05$, maka fixed effect

Jika Prob. Cross section random > 0,05, maka random effect.

Setelah melakukan Uji Chow dan Uji Hausman, kemudian dilanjut dengan uji regresi data panel dengan persamaan sebagai berikut:

Persamaan Regresi Model :

$\mathrm{ROE}=\beta_{0}+\beta_{1} \mathrm{STD}+\beta_{2} \mathrm{LTD}+\beta_{3} \mathrm{TD}+\mathrm{e}$

Keterangan:

$$
\begin{aligned}
& \text { ROE }=\text { Return On Equity } \\
& \text { STD }=\text { Short Term Debt } \\
& \text { LTD }=\text { Long Term Debt } \\
& \text { TD }=\text { Total Debt } \\
& \beta_{0}=\text { Konstanta } \\
& \beta_{1}, \beta_{2}, \beta_{3}, \beta_{4}=\text { Koefisien regresi variabel } \\
& \mathrm{e} \quad=\text { Standart Error }
\end{aligned}
$$

\section{Uji Parsial (T)}

Uji parsial (uji statistik $\mathrm{T}$ ) digunakan untuk mengetahuipengaruh dari masing-masing variabel independen terhadap variabel dependen. Kriteria dalam uji $\mathrm{T}$ ini adalah sebagai berikut :

- Jika nilai koefisien menunjukkan positif, maka variabel independen berpengaruh positif terhadap variabel dependen.

- Jika nilai koefisien menunjukkan negatif, maka variabel independen berpengaruh negatif terhadap variabel dependen.

\section{Uji Koefisien Determinasi (R2)}

Uji ini digunakan untuk mengukur seberapa jauh kemampuan model regresi dalam menjelaskan variasi variabel dependen (Ghozali, 2011). Nilai koefisien determinasi besarnya antara 0 (nol) dan 1 (satu). Apabila nilai R2 mendekati 0, maka kemampuan variabel independen dalam menjelaskan variabel dependen masih terbatas. Sebaliknya, jika nilai R2 mendekati 1, maka kemampuan variabel independen dalam menjelaskan variabel dependen cukup baik.

\section{HASIL PENELITIAN DAN PEMBAHASAN}

\section{Hasil Penelitian}

\section{Current Ratio}

Berdasarkan data diatas menunjukkan bahwa Current Ratio pada sampel perusahaan makanan dan minuman memiliki rata-rata 219.4961, niilai tertinggi sebesar 868,78, dan nilai terendah sebesar 51,39. Dengan standar deviasi sebesar 185.2817. perusahaan deng Current Ratio tertinggi adalah DLTA sedangkan perusahaan dengan Current Ratio terendah adalah MBLI.

\section{Return On Asset}

Berdasarkan data diatas dapat dijelaskan bahwa Return on Asset (ROA) menunjukkan rata-rata sebesar 9.462727, dengan nilai tertinggi 52.67, nilai terendah -9.71, dan standar deviasai sebesar 12.85855. perusahaan dengan niali ROA tertinggi adalah MLBI, sedangkan yang terendah adalah AISA.

\section{Debt To Equity Ratio (DER)}

Berdasarkan data diatas menunjukan bahwa Debt to Equity Ratio (DER) dengan rata-rata 1.012667 , nilai tertinggi 1.77 , nilai terendah 0,088 , dan standar deviasi 0.482006. Perusahaan dengan nilai DER tertinggi ialah MLBI, dan nilai terendah yaitu INDF.

\section{Harga Saham}

Harga saham berdasarkan data diatas dengan rata-rata 3.273856 , nilai tertingii 4.44208736, nilai terendah 2.086359831, dan standar deviasi 0.624270. Perusahaan dengan harga saham tertinggi adalah MYOR dan terendah adalah PSDN.

\section{Uji Normalitas}




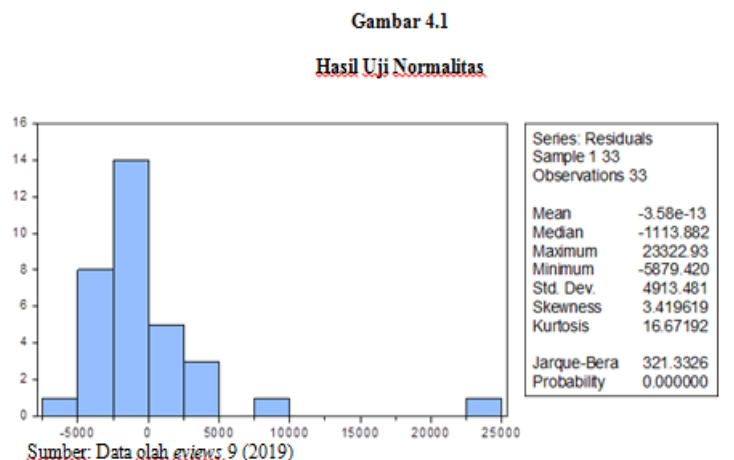

Dari hasil 4.1 tersebut didapatkan hasil Jarque-Bera 321.3326 dengan Probability 0.000000 dimana lebih kecil dari 5\%(0.05). Sehinggal hal tersebut menunjukkan bahwa residual data dalam penelitian ini berdistribusi tidak normal.

Gambar 4.2

Hasil Uji Normalitas
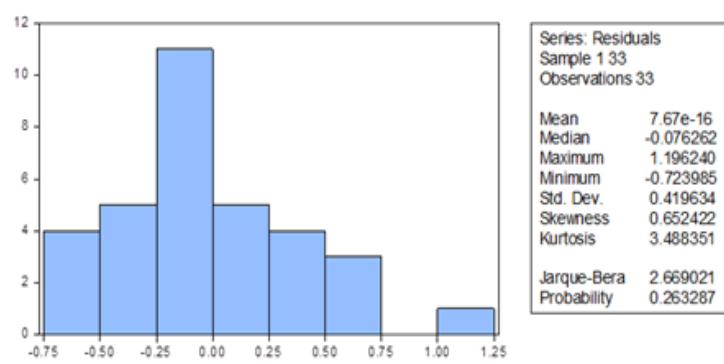

Berdasarkan hasil pengujian kedua dengan melogaritma harga saham dari gambar 4.2 dapat disimpulkan bahwa residual persamaan regresi pada penelitian ini mempunyai distribusi normal. Hal ini terlihat pada nilai Jarque-Bera sebesar 2.66021 dengan nilai Probability 0.263287 yang mana lebih besar dari alpha $5 \%$ (0.05). sehingga dapat disimpulkan penelitian ini berdistribusi normal.

\section{Uji Autokorelasi}

Table 4.2

Hasil Uji Autokorelasi

Breush-Grodfrey Serial Correlation LM Test

\begin{tabular}{|c|c|c|c|}
\hline F-Statistik & 2.813071 & Prob. F(2.27) & 0.0777 \\
\hline Obs ${ }^{*}$ R-squared & 5.690810 & Prob. Chi-Square(2) & 0.0581 \\
\hline
\end{tabular}

Berdasarkan hasil ujia BreuschGrodfrey pada table diatas terlihat bahwa niali prob. Chi-Square sebesar 0.0581 yang mana lebih besar dari 0.05 (prob. BreuschGrodfrey > 0.005) sehingga dalam pengujian ini tidak terjadi masalah autokorelasi.

\section{Uji Heteroskedasitas}

Iapel 4.5

Hasil Uji Heteroskedastisitas

Hereroskedasticity Test: White

\begin{tabular}{|c|c|c|c|}
\hline F-Statistik & 0.553516 & Prob. F(9.23) & 0.8201 \\
\hline Obs *Rsquared & 5.875078 & $\begin{array}{c}\text { Prob. Chi- } \\
\text { Square(9) }\end{array}$ & 0.7524 \\
\hline Scaled explained SS & 5.644992 & $\begin{array}{c}\text { Prob. Chi- } \\
\text { Square(9) }\end{array}$ & 0.7749 \\
\hline \multicolumn{3}{|c|}{ Sumber: Data dioalah sxws 9 (2019) }
\end{tabular}

Dari hasil tabel tersebut dapat dilihat tidak terdapat gejala hereroskedastisitas dengan uji white yang menunjukkan nilai prob. Chi-square sebesar 0.7524 lebih besar dari pada 0.05 penelitian ini tidak terdapat adanya heteroskedastisitas.

\section{Uji Multikolineiritas}

Tabel 4.4

Uji Multikolinearitas

(Koefesien Korelasi)

\begin{tabular}{|c|c|c|c|}
\hline & CR & ROA & DER \\
\hline CR & 1.000000 & 0.210269 & -0.684653 \\
\hline ROA & 0.210269 & 1.000000 & -0.065179 \\
\hline DER & -0.684653 & -0.065179 & 1.000000 \\
\hline
\end{tabular}

Pada pengujian korelasi atau varibel independent tabel 4.5 diatas menunjukkan adanya korelasi (derajat kertaan) yang rendah $(<90 \%)$ atau variable independent ini menunjukkan bahwa tidak ada pengaruh yang signifikan dan tidak saling berkorelasi antara varibel independent ini menunjukkan tidak adanya gejala multikolinearitas.

\section{Uji Regresi (Random Effect)}


Iabel 4.1

Hasil Uji Regresi Data Panel

Model Random Effect

\begin{tabular}{|c|c|}
\hline Variabel & Coeffecient \\
\hline C & 3.042702 \\
\hline Curret Ratio & 0.000530 \\
\hline Return on Asset & 0.014645 \\
\hline Debt to Equity Ratio & -0.023488 \\
\hline
\end{tabular}

Dari hasil regresi data panel diatas maka diperoleh persamaan analissi regresi sebagai berikut:

a. Nilai Konstanta dalam persamaan regresi adalah 3.042702 menyatakan bahwa jika Current Ratio (CR), Return On Asset (ROA), dan Debt To Equity Ratio $(D E R)$ nialinya 0 (nol) maka nilai harga saham sebesar 3.042702.

b. Koefesien regresi untuk Current Ratio $\left(\mathrm{X}_{1}\right)$ mempunyai nilai sebesar 0.000530 artinya jika nilai CR naik $1 \%$ maka akan menyebab kenaikan harga saham sebesar $0.053 \%$ dan sebaliknya jika CR turun $1 \%$ maka harga saham akan turun sebesar $0.0530 \%$.

c. Koefesien regresi untuk Return on Asset $\left(\mathrm{X}_{2}\right)$ mempunyai nilai sebesar 0.014645 artinya jika ROA naik $1 \%$ maka akan menyebabkan kenaikan sebesar $1.4645 \%$ terhadap harga saham dan sebaliknya jika ROA turun $1 \%$ maka akan terjadi penurun terhadap harga saham sebasar $1.4645 \%$.

d. Koefesien regresi untuk Debt to Equity Ratio $\left(\mathrm{X}_{3}\right)$ mempunyai nilai sebesar -0.023488 artinya jika DER naik $1 \%$ maka akan menyebabkan penurunan harga saham sebesar -2.3488 dan sebaliknya jika DER terjadi penurunan makan akan menyebabkan kenaikan harga saham sebaesar -2.3488 .
Tabel 4.8

Uji Pengaruh Parsial

\begin{tabular}{|c|c|c|}
\hline Yariabel & Probabilitas & Keterangan \\
\hline Current Ratio & 0.6225 & Tidak Signifikansi \\
\hline Retrun On Asset & 0.0018 & Signifikansi \\
\hline Debt To Equity Ratio & 0.5661 & Tidak Signifikansi \\
\hline \multicolumn{2}{|l|}{ Sumber:Data dioalha eviows 9 (2019) }
\end{tabular}

Berdasarkan hasil pengujian $\mathrm{Uji} T$ atau Uji Parsial pada table 4.10 antara CR terhadap harga saham, ROA terhadap harga saham, dan DER terhadap harga saham sebagai berikut:

1) Uji hipotesis yang pertama yaitu ada atau tidak adanya pengaruh antara CR terhadap harga saham. Pengujian hipotesis pertama dalam penelitian ini membandingkan nilai sigifikansi dengan alpha 5\%. Dari hasil pengujian tersebut menunjukkan bahwa niali prob. Sebesar $0.6225>$ 0.05 artinya variable Current Ratio secara parsial berpengaruh positif dan tidak signifikan terhadap harga saham.

2) Pada pengujian hipotesis yang kedua yaitu ada atau tidaknya pengaruh ROA terhadap harga saham. Dimana pengujiannya ini membandingkan signifikansi dengan alpha 5\%. Berdasarkan hasil pengujian ROA dimana nilai prob. Sebesar $0.0018<$ 0.05 artinya variable Return on Asset secara parsial berpengaruh positif dan signifikansi terhadap harga saham.

3) Uji hipotesis yang ketiga antara DER terhadap harga saham, yaitu untuk mengetahui ada atau tidaknya pengaruh. Pengujiannya ini membandingkan signifikansi terhadap alpha 5\%. Dari hasil pengujian menunjukkan nilai prob. Sebesar $0.5661>0.05$, artinya variable tidak berpengaruh negatif dan tidak signifikan terhadap harga saham.

\section{Uji Parsial (T)}


Pembahasan

\section{Analisis Pengaruh Current Ratio (CR) terhadap harga saham}

Dari hasil uji parsial (uji T) diperoleh nilai prob. CR sebesar 0.6225 , nilai koefesien sebesar 0.000530. Nilai prob. Tersebut lebih besar dari 0.05 $(0.6225>0.05)$ hal ini menunjukkan bahwa CR berpengaruh positif dan tidak signifikan terhadap harga saham. Sehingga hipotesis menyatakan ditolak bahwa rasio CR berpengaruh positif dan tidak signifikan terhadap harga saham. Konsisten dengan penelitian Suharno (2017) yang menyimpulkan bahwa CR tidak berpengaruh secara signifikan terhadap harga saham. Currrent Ratio yang rendah menunjukkan adanya masalah dalam likuiditas perusahaan. Curren Ratio yang tinggi juga belum tentu menunjukkan perusahaan yang baik, hal ini dikarenakan adanya kemungkinan terdapat banyak dana perusahaan yang tidak berputar, dengan kata lain terjadi penurunan produktivitas karena aktivitas menurun dan pada akhirnya akan mengurangi pendapatan laba perusahaan.Dalam hal ini penilaian harga saham melalui tingkat Current Ratio suatu perusahaan bukan merupakan satusatunya rasio yang mempengaruhi harga saham perusahaan tersebut, karna bagaimanapun juga masih ada rasio likuiditas lainnya yang memiliki kemungkinan berpengaruh terhadap kinerja keuangan suatu perusahaan dan pada akhirnya akan memberikan pengaruh terhadap harga saham.

\section{Analisis Pengaruh Return On Asset (ROA) terhadap harga saham}

Dari hasil uji parsial (uji t) diperoleh bahwa nilai probabilitas Return On Asset (ROA) sebesar 0.0018 dan nilai koefisien sebesar 0.014645. Nilai probabilitas tersebut lebih kecil dari 0.05 (0.0018 $<0.05)$ hal ini menunjukkan bahwa hipotesis Return On Asset diterima, karena berpengaruh positif dan signifikan terhadap harga saham. Hasil temuan ini mendukung penelitian. Sejalan dengan hasil penelitian yang dilakukan Permatasari (2010) yang menyatakan bahwa terdapat pengaruh positif ROA terhadap harga saham dan penelitian yang dilakukan Sri Zuliarin (2012) menunujukkan bahwa ROA berpengaruh siginifika positif terhadap harga saham. Return on Asset (ROA) menjelaskan bahwa semakin tinggi rasio ini menunjukkan bahwa perusahaan semakin efektif dalam manfaatkan aktiva untuk menghasilkan laba bersih setelah pajak. Dengan demikian, semakin tinggi ROA, kinerja perusahaan akan semakin efektif dan akan meningkatakan daya tarik perusahaan terhadap investor. Hal ini akan berdampak pada permintaan harga saham di pasar modal, sehingga dengan mekanisme pasar harga saham meningkat.

\section{Analisis Pengaruh Debt to Equity Ratio (DER) terhadap harga saham}

Dari hasil uji parsial (uji t) diperoleh bahwa nilai probabilitas Debt to Equity Ratio (DER) sebesar 0.05661 dan nilai koefisien sebesar -0.023488 . Nilai probabilitas tersebut lebih kecil dari 0.05 $(0.05661>0.05)$ hal ini menunjukkan bahwa hipotesis Debt to Equity Ratio berpengaruh negatif dan tidak signifikan terhadap harga saham. Sejalan dengan penelitian yang dilakukan oleh Muskal menunjukkan bahwa Debt to Equity Ratio menunjukkan tidak ada pengaruh positif dan tidak signifikan terhadap harga saham. Hal ini sesuai dengan teori yang dikemukkan oleh Sudana (2009:23) semakin besar rasio ini menunjukkan porsi penggunaan utang dalam membiayai investasi pada aktiva semakin besar, yang berarti pula risiko keuangan perusahaan meningkat dan sebaliknya.

\section{KESIMPULAN DAN SARAN}

\section{Kesimpulan}

Penelitian ini bertujuan untuk mengetahui rasio keuangan terhadap 
kinerja keuangan pada perusahaan Makanan dan Minuman yang terdaftar di Bursa Efek Indonesia (BEI) periode 20152017. Pada penelitian ini variabel dependen yang digunakan adalah harga saham. Sedangkan variabel independen dalam penelitian ini yang digunakan adalah Current Ratio (CR), Return On Asset (ROA), dan Debt To Equity Ratio (DER).

1. Variabel Current Ratio (CR) secara parsial berpengaruh positif dan signifikan terhadap harga saham, hal ini menunjukkan bahwa hipotesis pertama $(\mathrm{H} 1)$ ditolak.

2. Variabel Retrun On Asset (ROA) secara parsial berpengaruh positif dan signifikan terhadap harga saham, hal ini menunjukkan bahwa hipotesis kedua (H2) diterima.

3. Variabel Debt To Equity Ratio (DER) secara parsial tidak berpengaruh negative dan tidak siginifikan terhadap harga saham, hal ini menunjukkan bahwa hipotesis ketiga (H3) diterima.

\section{Saran}

Berdasarkan hasil penelitian ini, peneliti berharap untuk penelitian selanjutnya perlu memperhatikan beberapa hal sebagai berikut:

1. Bagi Investor dalam mengambil keputusan berinvestasi baiknya memperhatikan rasio-rasio yang ada dan mempelajari setiap pergerakan harga saham dan memperhatikan kinerja keuangan perusahaan melalui rasio-rasio keuangan yang tertera di idx

2. Jumlah variabel yang dimasuk kan baiknya ditambah agar hasilnya penelitian lebih optimal, karena semakin banyak data semakin baik untuk diolah selanjutnya.

\section{DAFTAR PUSTAKA}

Heni, Setianingsih. 2006. Anlisis FaktorFaktor Yang Mempengaruhi Harga Saham Pada Perusahaan yang tergabung dalam kelompok LQ45 di Bursa Efek Jakarta. Skripsi. Yogyakarta: UAD.

Sartono, Agus. 19998. Manajemen Keuangan. Edisi ketiga, Cetakan Keempat. Yogyakarta: BPFE UGM.

Suhadi, Dady. 2009. Pengaruh Rasio Aktivitas, Rasio Profitabilitas, Rasio Laverage, dan Rasio Penilian Terhadap Harga Saham Perusahaan Food and Beverage. Skripsi. Yogyakarta.

Halim, Abdul. 2003. Analisis Investasi. Jakarta: Salemba Empat.

Jogiyanto H.M, 2000. Teori Portofolio dan Analisis Investasi. Penerbit BPFE, Yogyakarta.

Denies, Priatinah, Kusuma, Adhe, dan Prabandaru. 2012. Pengaruh Return on Asset (ROI), Earning Per Share (EPS), dan Deviden Per Share (DPS) Terhadap Harga Saham Perusahaan Pertambangan Yang Terdaftar di Bursa Efek Indonesia (BEI) Periode 2008-2010. Jurnal Nominal, Vilume I, No I.

Anoraga, Padji. 2001. Pengantar Pasar Modal Indonesia. Jakarta: Mediasoft Indonesia.

Ghozali, Imam. 2011. Aplikasi Analisis Multivariate Dengan Program IBM 19 edisi lima spss. Semarang: Badan Penerbit UNDIP.

Harahap, Sofyan Syafri. 2015. Analisi Kritis Atas Laporan Kuangan. Jakarta: PT. Raja Grafindo Persada.

Horne, James c. Van, dan Wachowicz, John M. 2005. Prinsip-Prinsip Manajemen Keuangan. Jakarta: Salemba Empat. 
Zuliarni, Sri. 2012. Pengaruh Kinerja Keuangan Terhadap Harga Saham Pada Perusahaan Mining And Mining Service Di Bursa Efek Indonesia (BEI). Jurnal Aplikasi Bisnis. Hal. 43-47. 